\title{
USING DEBATING ACTIVITIES TO FOSTER STUDENTS' COMMUNICATION AND CRITICAL THINKING SKILL
}

\author{
Deni Asrida \\ Program Studi Pendidikan Bahasa Inggris Jurusan Tarbiyah STAIN Batusangkar \\ Korespondensi : Jln. Batu Tujuh Tapak Mandahiling Sungai Tarab Kec. Sungai Tarab \\ Batusangkar Sumatera Barat. E-mail: deni_asrida81@yahoo.co.id
}

\begin{abstract}
This article discusses about the use of the debating activities in fostering students' communication and critical thinking skills. The aims of debating are to enable the students to be active and creative in the classroom. Debating is also assumed as a valuable learning activity for teaching critical thinking and improving communication skills. Debating is an effective pedagogical way because of the level of responsibility for learning and active involvement required by all student debaters. Many teachers realize that the best strategy for motivating the students to communicate in English is by changing the situation in the class. By creating an interesting and motivating environment, the students are expected to be immersed in the activities given by the teachers. Moreover, an ideal teacher should provide opportunities for students to talk by using group work or pair work, and limiting teacher talk. Therefore, the teacher should keep encouraging the students to get involved during the process of learning in the class most of the time.
\end{abstract}

Kata kunci: debating, foster, communication, thinking skill

\section{INTRODUCTION}

peaking is one of the four skills that the students should master in learning English. Being good at speaking means being able to share one's ideas and opinions to listeners through English. Moreover, among the four skills (listening, speaking, reading and writing), speaking seems intuitively the most important since most foreign language learners are primarily interested in learning to speak. Thus, by mastering the speaking skill people can carry out conversations with others fluently.

However, the use of English for speaking is not simple for the students, because they have to master several important elements, such as pronunciation, grammar, vocabulary, fluency and comprehension. These elements are very important in the communication because if they do not master all the elements of speaking, the communication will not run very smoothly. In addition, Bailey (2003:48) says that speaking in a new language is believed to be harder than reading, writing, or listening for two reasons. First, unlike reading or writing, speaking happens in real time: usually the person you are talking to is waiting for you to speak right then. Second, when someone speaks, he/she can not edit and revise what he/she wishes to say, as he/she can if he/she is writing.

English teachers have a responsibility to improve students' English speaking skill; therefore the 
teachers must have a good teaching method in order to solve the problems faced by the students in learning English. The teachers also need appropriate techniques in teaching speaking to make the students capable of being active and creative in the learning process in the classroom. In order to create effective learning activities in the classroom, the teachers should focus on the students' participation during the process of learning. Therefore, it can be said that one of the effective learning requirements in the classroom is that there is students' participation in the teaching and learning process. By doing this, the students' difficulties will be able to be solved.

Many teachers realize that the best strategy for motivating the students to communicate in English is by changing the situation in the class. By creating an interesting and motivating environment, the students are expected to be immersed in the activities given by the teachers. This idea is also supported by Bailey (2003: 48) saying that an ideal teacher should provide opportunities for students to talk by using group work or pair work, and limiting teacher talk. Therefore, the teacher should keep encouraging the students to get involved during the process of learning in the class most of the time.

Debate is assumed as a valuable learning activity for teaching critical thinking and improving communication skills. Debating is an effective pedagogical way because of the level of responsibility for learning and active involvement required by all student debaters. In debating activities the students are free to talk and give their opinions. In a particular debate, the speaker can give many arguments to share his ideas. Hence, the students can be motivated to think in a short time and give their arguments. Eventually they will be challenged to talk and speak up during the debating activities.

\section{DEBATING ACTIVITIES}

To foster students' communication and critical thinking skill and motivate them in speaking English, the teachers need to hold debates in the classroom because by doing this the students will be able to enrich and develop their critical thinking as well as their speaking skill. Debate is process of presenting idea or opinion which two opposing parties try to defend their idea or opinion. Krieger (2005) says that Debate is an excellent activity for language learning because it engages students in a variety of cognitive and linguistic ways. Halvorsen (2005) says that debate forces students to think about the multiple sides of an issue and it also forces them to interact not just with the details of a given topic, but also with one another. From the opinions above we can conclude that debating is a clash of arguments for every issue. There are always different sides of the story and people support or disagree with certain issues. Debating seeks to explore the reasons behind each argument. To make those reasons understandable and convincing, debaters should deliver their arguments with good communication skills.

Mayuni et al (1995:42) states that debate is considered the most structurally exact form of persuasive speech. It usually focuses on a proposition of a controversial subject in which two opposing sides attempt to convince an audience that their ideas and argument are right. In addition, Mowbray and George (1992:67) say that debating is a way of arguing constructively. Debate is the process which determines how change should come about. From the above opinions we can conclude that debating activities in the classroom are very interesting and challenging because the students are encouraged to speak English fully and explore their ideas in a good way. 


\section{KINDS OF DEBATING}

According to Mayuni et al (1995:42) there are three types of debates, seen from the total number of participants in a debate. They are six person debates, whole class debates (consisting of two opposing sides) and two person debates. From its delivery method, debates can be categorized as follow: first, Parliamentary debates. In a parliamentary debate three speakers from the government and opposition, respectively deliver quite lengthy speeches in favor of, and against, a bill, amendment, or motion. After this, there is a question time, in which queries are directed at the Prime Minister, after which the leader of the opposition has the right of reply. Finally, the house votes and the bill is passed or lost.

Second, Formal debates. Formal debates consist of three speakers for the affirmative and three for negative. Respectively, each of the team delivers speeches of some 7-10 minutes. Each speaker is marked by a panel of adjudicators, and the marks for each team are finally added up to decide which team has won.

Third, Oregon debate. It resembles formal debate, except that each speaker has the additional task of crossexamining for 3 minutes the previous speaker. Each team captain (usually number 3 on each side) has the right of reply. Each speaker's speech is marked in the usual way, and the winner of each cross examination is given a bonus mark. Finally, the winning team is announced by the adjudicators.

The fourth is Single debate. Single debates have just two speakers (the first affirmative, the second is negative) competing against one another. Each has the right of reply. Marks are allocated by adjudicators, and the winner is announced at the end.
According to Kennedy (2007) debate can be classified into four types. They are: (1) Fishbowl debate. The teacher divides the class into two groups, and each group works together to formulate arguments for their assigned viewpoint. After each side has presented their arguments, the groups give rebuttal back and forth. In another type of fishbowl debate the students are divided into three groups-one group of experts for each side of issues and the remaining students represent the audience. (2) Think pair share debate. Students' first think and make notes individually. Then they work in pairs to create lists of reasons to support both sides of an issue. Next, two pairs work together to come to a consensus on which side they wish to support and refine their list or reasons for that side. Finally, each group of four students shares its conclusion and supporting arguments with the whole class. (3) Problem solving debate. It involves eight participants, four on each side, debating a question such as "Should capital punishment be abolished?" in this format, the first two speakers present the historical and philosophical background information, the second set of speakers explains why changes are or are not justified, the third pair of speakers suggests a plan, and the last two speakers summarize the position of each team.

\section{PROCEDURE OF DEBATING ACTIVITIES}

There are some procedures of debate: according to Halvorsen (2005), there are six steps in debate: first, Students must first be made aware of a debatable topic and of the variety of potential positions that can be taken on the topic. Second, Students should then be given an opportunity to research the topic somehow and form their own 
opinions on the issue. Third, Next pairs or small groups should be formed where like-minded students can share their opinions on the topic and gain information from others. During this step students should be encouraged to think about the potential arguments that will come from the other side and how they can respond to these arguments. Four, Now some form of debate must take place where the two (or three or four) sides share their opinions and present their arguments. This could take the form of a classic debate, with opening and closing arguments from both sides and time for rebuttals all done as a class. Alternatively, it could simply be small groups or pairs sharing their differing points of view with one another. Five, the instructor should follow-up with a summary of the opinions and views expressed by all sides and an assessment of their strengths and weaknesses. Finally, the class and instructor should be allowed to express their opinions on which side made the case most convincingly. This step is important in that it helps the students to understand that this type of thinking and debate process can lead to real results and provide some sense of closure on the topic.

Dobson (1987) says that there are eight steps in debate procedure: first, describe the topic debate and ask which students would like to be: pro or con. Second, select an equal number of students to speak on each of the two debate "team". Third, allow the students sufficient time to prepare their argument. Four, have the two teams sit in front of the class so that the audience can see them. Five, appoint one member on each team as the captain. The captain will give his presentation first and summarize the team's views at the end. Six, set a three-minute time limit for each presentation and alternate a presentation by a team I member with one by a team II member. Seven, after everyone has given his presentation and the captains have summed up team views. The last, end the debate when the subject is exhausted or if the students get involved in heated argument.

According to Depdiknas (2009) the Indonesian schools debating championships use the World School Format as follows: first of all, there are 2 teams debating, each consisting of 3 (three) debaters who would be $1^{\text {st }}, 2^{\text {nd }}$ and $3^{\text {rd }}$ speakers of the team. Second, One team shall be the government or affirmative side. This is the side agreeing with the motion. The other team shall be the opposition or negative side. This is the side disagreeing with the motion.

Third, each speaker will deliver a substantial speech of 8 (eight) minutes in duration, with the affirmative going first. Afterward, either the $1^{\text {st }}$ or $2^{\text {nd }}$ speaker on both sides will deliver the reply speeches of 4 (four) minutes in duration, with the negative going first.

Thus, the complete order of speaking during a debate is as follows:

Table I: Complete order of speaking

\begin{tabular}{ccc}
\hline No & \multicolumn{2}{c}{ Group } \\
\hline 1 & $1^{\text {st }}$ Affirmative & $1^{\text {st }}$ Negative \\
\hline 2 & $2^{\text {nd }}$ Affirmative & $2^{\text {nd }}$ Negative \\
\hline 3 & $3^{\text {rd }}$ Affirmative & $3^{\text {rd }}$ Negative \\
\hline
\end{tabular}

After that, in a substantive speech, members of the opposing team are allowed to give an interruption, called Points of information (POI), to the speaker delivering the speech. POIs may be delivered between $1^{\text {st }}$ and $7^{\text {th }}$ minute of the speech. Then, a time keeper shall signal the time. There will be one knock at the end of the $1^{\text {st }}$ and $7^{\text {th }}$ minutes, to signal the starting and ending times for POI. And two knocks at the $8^{\text {th }}$ minute to signal that delivery time for the speech has ended. Any debater speaking after 8 minutes 30 seconds shall be considered overtime and her points could be reduced as well. 
In addition, for reply speeches, there will be one knock at the $3^{\text {rd minute }}$, to signal that delivery time is almost over, and two knocks at the $4^{\text {th }}$ minute. Every debate shall be judged by an odd number of judges and only the judges shall decide who wins the debate (there is no draw in the result of a debate). Last, In Indonesian debate, every team is given 30 minutes preparation time after the motion is released and before the debate begins. During this preparation time, teams are not allowed to get help from anybody, or use dictionaries, or any communication devices. From the procedures above it is obvious that each of the speakers has a different job in the debating activities. Each of the speakers has to prepare himself before the debate begins, for example, searching for the information about the issues being debated. In addition, the members of the teams need to have sufficient preparation in order to be successful.

Moreover, Mayuni at al (1995: 46) adds some more opinions to conduct the debate: first, The chairperson welcomes the audience, announces the subject, introduces the two teams (their stance relative to the subject, and each speaker's name), describes the condition of the debate and introduce the adjudicators and then first speaker for the affirmative case open the debate, and so through both team, finally asking the adjudicator to deliver his opinions and announce the winning team. Second, the first affirmative speaker introduces the topic, providing a working definition and outlining the major reasons for his/her team's support of the topic statement.

$\mathrm{He} / \mathrm{she}$ then argues the points allotted as a way of introducing the affirmative case, and finally summarizes what has been said. Third, the first negative speaker either accepts, rejects or modifies the affirmative's definition of the topic, then outlines the negative team's major affirmative reasons for rejecting the topic statement. Then he/she argues the points allotted, introducing the body of the negative case, and finally summarizing what has been said.

Next, the second affirmative speaker may offer further comment on the matter of basic definitions of the topic, before attacking the negative case in general and rebutting the first negative's allotted points specifically. $\mathrm{He} / \mathrm{she}$ then advances the remaining arguments of the affirmative case, and summarizes. After that, the second negative speaker may attempt to conclude any dispute over definitions, and then refute the second affirmative's allotted points, before going on to the last points of the negative case, and summarizing. Next, the third affirmative speaker rebuts the second negative's points, and may add any final points of the affirmative case. He/she then compares the two cases overall, arguing why the affirmative is the more weak and summarizing the whole debate to reflect well upon his/her team.

Finally, the third negative speaker rebuts the third affirmative's points, and then presents his/her overall comparison of the two cases so as to make the negative out to be better. $\mathrm{He} / \mathrm{she}$ is not allowed to introduce any new points. After that, the adjudicator now presents his/her analysis and evaluation of each team. To assist in this task, he/she will have written down notes and marks for each speaker (judging matter, manner and method separately) while the debate was in progress.

\section{ADVANTAGES OF DEBATING ACTIVITIES}

Hyland (1993:25) says that debating has several advantages for the students such as: (1) debate can motivate the students since the students will be 
ensured that the communication acts they are doing have a real purpose instead of mere make believe. (2) Debate can develop the fluency in communication using the target language. Students are motivated to communicate using the target language because they are immersed in environment where language becomes a primary necessity, such as in debate. (3) It is a combination of the skills in the language. It gives opportunity for the students to apply their language skills and also develop cross cultural adeptness and second language capability. (4) It motivates the students to be active participants in the discussion among their friends. (5) It can reduce the student's anxiety since the students are not evaluated nor corrected in detail in relation to his/her capability in second language.

Moreover, Setiawan (2006: 79) says that there are some benefits to be gained through debating activity as the following: Increase self-confidence, Increase the effort of achievement, Good capability in convincing others, Ability to describe problems in clear and in depth detail, Capability to foster rational thinking in terms of minutes, Capability of formulating problems in structured way, in clear flow, by stating the problems, evidence and inferring the evidence to answer the initial problems without any difficulty in thinking, Capability to debate well and defend argument well, Capability to build a case in a meaningful way and to see through the arguments of the opponents, and the last is having good techniques in argumentation without being drowned in emotion.

In addition, debate can improve

the students speaking skill and motivation. There are several advantages of doing debate in the classroom such as: debating is a sport of mind and voice, debating can create the skills you need for success, debate can give the power to change things.

Based on the above opinions we can conclude that by doing debate in the classroom the students' speaking skill will be optimalized since it can build the students self confidence to talk in the classroom and motivate them in studying the language.

\section{DEBATING ACTIVITIES AND CRITICAL THINKING SKILL}

Debating activities can foster students' communication and critical thinking skill because the students have to think in a very short time when speaking. They have to be able to deliver their arguments or ideas based on the facts and evidences. There are some definitions of critical thinking from the experts as in Ennis (1985: 28) defines critical thinking as "reasonable, reflective thinking that is focused on deciding what to believe or do". Stall and Stahl (1991:82) found the most popular conception of the term to be the development of "cohesive, logical reasoning patterns and understanding assumptions and biases underlying particular positions". Gieve (1998:126), meanwhile, states that for students to think critically they must be able to "examine the reasons for their actions, their beliefs, and their knowledge claims, requiring them to defend themselves and question themselves, their peers, their teachers, experts, and authoritative texts".

From the opinions above we can conclude that through debating activities the students can develop and improve their critical thinking skill in debating. It means they have to think logically about an issue in debating. They have to have facts and evidences when delivering their ideas to his/her opponent in debating. In debating activities the students can do these following steps in 
order to have critical thinking in debating:

1. Identify and clarify the issue (Interpretation)

2. Gather and organize information about the issue (Analysis)

3. Evaluate that information for accuracy and applicability (Evaluation)

4. Draw conclusions from the evidence (Inference)

5. Explain conclusions logically in the form of a debate (Explanation)

6. Critically appraise and examine one's performance (Selfregulation)

\section{BIBLIOGRAPHY}

Bailey, Kathleen. 2003. Practical English Language Teaching: First Edition. New York: McGraw-Hill Companies,Inc.

Departemen Pendidikan Nasional. (2010) English Debate Training for High School Teachers in Tanah Datar. Jakarta. Direktorat Pembinaan Sekolah Menengah Atas.

Dobson, M Julia. 1987. Effective techniques for English conversation groups. Washington

Ennis, R. (1985). Critical thinking and the curriculum. National Forum, $65,28-31$.

Gieve, S. (1998). Comments on Dwight Atkinson's 'A critical approach to critical thinking in TESOL. TESOL Quarterly, 32(1), 123-129.

Halvorsen andy 2005. Incorporating critical thinking skills development into ESL/EFL course.

http://iteslj.org/Techniques/Halvor sen-CriticalThinking.html

\section{CONCLUSIONS}

Debating activities can be used as one the teaching techniques to help the students to improve their communication and critical thinking skill. Debate is assumed as a valuable learning activity for teaching critical thinking and improving communication skills. Hence, the students can be motivated to think in a short time and give their arguments. Eventually they will be challenged to talk and speak up during the debating activities.

Retrieved February 15, 2010 at $10: 45$

Hyland, Ken. 1993. Why Don't teachers Learn What Learners Learn?Taking The Guesswork Out With Action Logging. Washington DC.

Ilza Mayuni et al. 1995. Speaking Book III. Padang: Fakulatas Pendidikan Bahasa dan Seni IKIP Padang

Kennedy, Ruth. 2007. In-Class Debates: Fertile Ground for Active Learning and the Cultivation of critical Thinking and Oral Communication skills. International Journal of Teaching and Learning in Higher Education, Vol 19, Retrieved on June $15^{\text {th }} 2011$

Krieger, Daniel 2007. Teaching debate to ESL students: a six-class unit. http://iteslj org/Techniques/Krieger-

Debate.html Retrieved January 24, 2010 at $10: 35$

Mowbray \& George. 1992. Modul 7: The art of Debating. from http://www.asked.gov.sk.ca/does/c 
om20/mod7.html. Retrieved on July $25^{\text {th }} 2011$

Setiawan, R. 2006. Debate as a means to improve communication strategy. Jurnal ilmu-ilmu social, Vol 2 No. 1. 1858-2265.

Indeks

debating...... 1, 150, 151, 152, 153, 154, 155

foster

$1,150,154$
Stall, N.N., \& Stahl, R.J. (1991). We can agree after all! Achieving consensus for a critical thinking component of a gifted program using the Delphi Technique. Roeper Review, 14(2), 79-88.

skill $1,150,154,155$ 